opinion of the situation in the country, the public perception of the local anti-graft organisation, and the community's individual attitude towards corrupt practices.

It would have been ideal, if the author could have drawn upon his own immense practical experiences and highlighted some key case studies - without revealing actual names. Real cases leave a lasting trail.

Finally, de Speville has dedicated his book to "To all those who long for freedom from corruption," and this clearly includes every member of every society who cares for their nation. Therefore, this simple book deserves our full attention.

\title{
Response to Daniel Martin Varisco: Review of Christoph Marcinkowski (transl., intro.): Measures and Weights in the Islamic World. An English Translation of Professor Walther Hinz's Handbook 'Islamische Maße und Gewichte', with a foreword by Professor Clifford Edmund Bosworth, FBA
}

(Kuala Lumpur: ISTAC 2003), xxii, 98 pp. ISBN 983-9379-27-5.

In: Journal of the American Oriental Society 125, no. 2 (2005), 333-5.

\section{Christoph Marcinkowski International Institute of Advanced Islamic Studies (IAIS) Malaysia}

Since its publication, Measures and Weights in the Islamic World has established itself as a standard work - at least in the English-speaking Muslim world.

There can be no doubt that reviews, when done out of purely professional interest, might be considered a valuable tool for raising scholarly standards. The reviewer is not personally known to me as we are apparently working in different fields - Varisco (Hofstra University, Hempstead NY, United States) seems to be largely involved in anthropology, with emphasis on Yemen, whereas I have so far contributed toward the study of contemporary and historical Shi' ism as well as security issues and Iranian Studies. However, the overall tenor of the wording of Varisco's review as well as what he deigned to present to his audience as 'facts' do require a stern response $^{1}$ in order to re-establish a climate of mutual respect and fairness among colleagues. For matters of brevity, I should like to focus in the following on only some selected issues:

(i) his criticism of the purpose and usefulness of the work under review;

(ii) matters of translation;

(iii) some basic advice on collegiality and fairness.

To begin with (i), Varisco (pp. 333-4) doubted the purpose of my translation of a work that had been published in German by the late Professor Walther Hinz several 
decades back. The reviewer considers my translation "unnecessary", as - in his view - a basic "working knowledge" of German could be expected from scholars (sic!) "who should either know a little German or could with minimal effort consult the Hinz original with a basic German dictionary" (ibid.).

In response, I should like to mention that Hinz's intricate style might often tell otherwise. More seriously, however, anyone who is browsing the bibliographies of works published in particular in the United States - at least in Islamic studies - will find that references given therein to German sources are often reproduced ('copypasted'?) faultily. To the point: although this might not apply to earlier periods of rather more thorough European scholarship on Islam, the purpose of a translation of a scholarly work from German into English during our times does serve an obvious purpose and needs no justification whatsoever.

More grave, however, is Varisco's erroneous suggestion to the reader that my translation was targeted primarily at a scholarly audience in the Western Islamic studies industry. I cannot help but consider this a falsification of the facts: in my own introduction I have clearly and unmistakably stated that

[...] during my teaching I have observed that my students face problems with regard to converting measures and weights, which they frequently encounter $[\ldots]$. Since they usually have no command of the German language, they are not aware of Professor Hinz's momentous contribution. I thus felt compelled to prepare my own 'teaching-material'.

The book has thus explicitly been published by me with a renowned Muslim institution of higher learning - ISTAC - and with a mainly Muslim audience in mind, although I could have done easily otherwise. It is thus the producing of wrong premises and their presentation as 'facts' to prospective readers of my book which has to be branded here.

On a more positive note, however, Varisco has - rightly - pointed out (and has quoted to that effect various sources) that new work has appeared since the publication of Hinz's German book - sources though that are mostly scattered over several journals. However, again, and in line with what has been said above in terms of the target group, I have never claimed that this translation would be the dernier cri. The audience was mainly restricted to undergraduate students in institutions of Islamic learning in the English-speaking parts of the Muslim world in order to provide them with basic knowledge of their heritage. (Other points of the reviewer's criticism against Hinz's (!) work shall not be addressed here.)

(ii) The reviewer had also something to criticise on the translation itself (p. 334), whereas other scholars of rather more senior standing than Varisco seem not to have found any serious faults with it. Thus it does not come as a surprise that Professor Clifford Edmund Bosworth FBA, for instance, one of Britain's leading scholars in Arabic and Islamic studies, whose German is excellent, states in his foreword to 
my translation, that he is "very happy to commend" it as Hinz's original German version "has stood the test of time and has not been replaced". ${ }^{3}$ Again, Professor Lawrence I. Conrad of Hamburg University in Germany writes in the Journal of the Royal Asiatic Society that

[...] Marcinkowski's translation is clear and accurate. He has incorporated into the text the revisions made by Hinz in his second edition, and for non-specialist readers he has also added explanatory notes on such matters as terms and names of cities, dynasties and individuals. The English rendering is therefore a welcome aid $[\ldots]{ }^{4}$

However, it is even more embarrassing and unfortunate that the American reviewer has been trying his hand (p. 334) at 'correcting' the German of the translator who is a native speaker of that language - a fact that might have been unknown to him. This assumes, at times, strange forms when, for instance, he is criticising my translation of German third-person references, such as "Sein erweiterter Wiederabdruck an dieser Stelle [...]", by erroneously referring "sein" to Hinz, when actually an earlier referred to scholarly article is meant. ${ }^{5}$ There are three genders in German, and in the above case "sein" substitutes a neuter (rather than a masculine noun or personal name, as erroneously assumed by the learned reviewer). This and other similar mistaken judgments leave Varisco's readers in a state of uncertainty in terms of his own German language credentials. In short, as I do not wish to venture doubting Varisco's knowledge of American-English, I should like to expect from him the same in return with regard to my own mother tongue - German. (By the way, on $p$. 334 of his review it should be "centre français" not "française"...)

Regarding (iii), i.e., the regrettable tenor of his review, some examples of which have already been given above, I would like to state the following: The study of a civilisation other than one's own requires a much deeper, finer, almost 'insiderlike' understanding of its 'working mechanisms' than, let's say, a mere appearance on the internet or elsewhere in the guise (and dress) of an eccentric Lawrence of Arabia-style 'friend of the Muslims' or than some comments on an online blogger site could offer. In terms of the genre of 'negative' review (radd in Arabic and traditional Islamic learning, but not entirely congruent with it), this would mean to retain always a respectful language - in spite of often harsh criticism of the topics at hand which, nevertheless, should be always based only on what an 'opponent' (or 'reviewed' author) has actually written (and not what he has not). Anything else would be either sharh, hāshiyah, tafsìr , or alike - 'commentary' or 'interpretation' etc. - but not scholarly review. It goes without saying that, aside from other requirements, a reviewer should be well-versed himself in the subject-matter of a reviewed work of another scholar and that the ethnic background or the religion professed by a 'reviewed' author should not play any part. I am saying this in 
particular with an eye on the current issues and misunderstandings between the United States and the Islamic world.

I should like to close with some words of sincere advice (nașịhah) on proper conduct $(a d a b)$ by the Haḍramī sage 'Abd-Allāh b. 'Alawī al-Ḥaddād (d. 1720), who said once that

[...] signs of humility include a liking for obscurity, dislike of fame, [and] acceptance of truth whether it be from a lowly or noble person. ${ }^{6}$

This humility would, of course, apply to both, the reviewer and the reviewed.

\section{Notes}

1. Contrary to professional academic practice, the Journal of the American Oriental Society, the publisher of Varisco's review, has declined to publish the rejoinder - although it has done so in the past with regard to American authors.

2. Marcinkowski (transl., intro.), Measures and Weights, xix (emphases mine).

3. Clifford Edmund Bosworth, "Foreword", in: Marcinkowski (transl., intro.), Measures and Weights, xv.

4. Lawrence I. Conrad, review of Marcinkowski (transl., intro.), Measures and Weights, in: Journal of the Royal Asiatic Society 14, no. 3 (November 2004), 266-7 (emphases mine).

5. Marcinkowski (transl., intro.), Measures and Weights, 1, n. 1 (emphases mine).

6. 'Abd-Allāh b. 'Alawī al-Haddād, "The Book of Assistance", SunniPath, also available online at http://www.sunnipath.com/Library/Articles/AR00000136.aspx (accessed on 6 December 2010). 